\title{
The Formation of the Modern Urban Environment Using Landscape Design Methods
}

\author{
Liubov Shabatura ${ }^{1, *}$, Natalia Bauer ${ }^{1}$ and Olga Iatsevich $^{1}$ \\ ${ }^{1}$ Industrial University of Tyumen, 625001 Volodarskogo str. 38, Tyumen, Russia
}

\begin{abstract}
The authors discuss the challenges, which face the person in relation to the culture of creating a sustainable urban environment. Urban environment is seen as space of human existence, influencing his spiritual and physical health. All the specialists engaged in the urban environment, think about the culture of its formation, unfortunately, only from an institutional point of view. Differently organized human environment inevitably affects the behavior, psycho - emotional state of a person, his perception and understanding of space. The cultural heritage of society fits in the space of an artificial environment that man has created and determines human behavior. To solve the problems of the urban environment, it is necessary to apply a set of interrelated technical, social, environmental, aesthetic and other measures. In this capacity, landscape design can be seen as a set of methods to create a sustainable urban environment to ensure harmonious living. The given paper presents the results of studies of innovative materials in the field of the modern urban environment.
\end{abstract}

\section{Introduction}

The urban environment in contemporary anthropological versions of the ontological theories appears as a space of human existence. Being as a symbol of culture, the city is a mechanism of its transformation into real life forms, makes up a socio-psychological entity and the human personality.

The problems of interaction of man and nature increase in proportion to the acceleration of scientific and technological progress and transformations of the urban environment. During the 20th century cultural landscapes of Russian cities are rapidly degraded, representing a system in stable disequilibrium with society. This is indicated by the facts that characterize the deterioration of the domestic urban environment.

Increasing diversity of the phenomena of modern society profoundly changes the nature of the design, evealing its capabilities in shaping the environment and impacts the environment of a human being. Modern landscape design becomes the design of environment, human experience design, social context. The subject of the design (in our case the urban environment) extends to the engineering, style and lifestyle, for creation a synthesis of meanings and human values.

*Corresponding author: shabatura@tsogu.ru 
The patterns and directions of development of the urban environment are interrelated with philosophy, religion, science, aesthetics, socio-economic relations, natural and climatic characteristics and culture of a particular country. The urban environment is being formed under the influence of processes taking place in society at each historical stage. At the same time, the urban environment has an impact on social well-being, worldview, attitudes, behavior and culture of the citizens [16]. Therefore, the urban environment must meet the functional, aesthetic, spiritual, cultural and human need, which contribute to the creation of favorable conditions for its vital activity.

The creation of habitat for human - creative, supportive, attractive, safe, harmonious, connecting the advantages of living in the city and the natural desire of citizens to nature, preservation of traditions and development, the introduction of new technologies - is one of the main challenges of a contemporary culture.

\section{Methodological bases of formation of the urban environment}

Questions of human perception of the city and the problems of mutual influence of the urban environment on a person have been considered by the thinkers long time ago. Thomas Moore in the XVI century described the ideal city in which domestic and spiritual needs of citizens are satisfied and social equality plays a dominating role. Next, Tommaso Campanella, Robert Owen, Saint-Simon, Charles Fure in their writings create an image of the "ideal" settlement. The problem of the "man in town" of the early urbanization affects Engels in "the condition of the working class in England". In his work "the City" M. Weber shows that cities in different countries and periods provide the basic needs of man in varying degrees. In the works of F. Braudel, "What is France?, L. Wirth, "Urbanization as a way of life", R. Park and E. Burgess, G. Simmel "Cities and spiritual life", F. Tennis "Community and society", J. Forrester "the Dynamics of city development", etc. the sociocultural living environment in the city is widely considered.

At all stages of human development the question of interaction with the surrounding material and spiritual environment were discussed. The sole existence, isolated from people who are look like you, was impossible. Starting from the primitive communal to the present time man has created a variety of settlements, organizing the environment with industrial and socio-cultural relations [1].

In the work "Decline of Europe" Spengler talked about the fact that every culture, running internal creative capabilities is mortified and goes into the phase of civilization (civilization, according to Spengler, is the end of any culture, its crisis) associated with an aggressive outward expansion, materialism, and technicism, as well as urbanization [17]. Rationalistic civilization, according to Spengler, is the degradation of the higher spiritual values of culture, doomed to destruction. In this case, the self-development of culture is possible only in the context of awareness of its stakeholders in the importance of fixation procedures, measurements, and the formation of images of the external world, or the environment in our understanding. Spengler warns that the immorality of hostile mass culture remains relevant in our time.

With the name of I. Kant is the basis of the submissions about ethical and aesthetical values of the landscape is closely connected. He urged to preserve for our posterity the variety of landscapes as inexhaustible sources of emotional wealth. Thus, I. Kant considered the subject of aesthetics as "the beautiful in art," but aesthetics, due to Kant, examines not only lovely but also makes judgments about the beautiful and accordingly is the "critique of aesthetic able to judge" [9, p. 273].

G. Hegel first raised the problem of the aesthetic ideal as a theoretical problem of philosophy of culture and aesthetics. In his "Lectures on aesthetics", Hegel defined art as "the manifestation of the ideal". In the creative process, it is very important aesthetic ideal, since it forms the taste of the artist, the taste of the public [6]. In addition, the great 
importance of the creativity of the designer is in shaping of the urban environment, which forms the taste and culture of the citizens.

Reflecting their professionalism, both designers and architects, and all the other professionals involved in the urban environment, think about the culture of formation, unfortunately, only from an institutional point of view. Consideration of landscape design with the means of prevention of further degradation of the urban environment is associated with overcoming such negative qualities connected with functional and aesthetic disorder of the inexpressiveness. The mere filling of space, vegetation is not enough to make the landscape with positive aesthetic qualities $[3$, p. 6]. . It is necessary to comprehend the possibilities of landscape design as one of the means of forming. It is worth saying, that in the "Lectures on the history of philosophy" the eminent philosopher argues, that philosophy is the basis of his age:" ...not only time comes when somebody begins to philosophize, but the folk develops a certain kind of philosophy, and this certainty, this view of thought, has the same certainty, which flows into all other historical sides of the national spirit; it is with them in the closest connection, with their Foundation". As G. Hegel says, this is "a certain image of philosophy, concurrent, therefore, with a certain way of the people among whom it acts, with their form of government, their morality, their social life, their healthy habits and comforts of life for their efforts and work in the field of art and science, with their religions ... in which he exercised his power this particular principle, and with the emergence and performance of new States, in which a higher principle finds its birth and development" [7, p. 111-112]. Mentioned "historic parts of the people's spirit" represent, in our opinion, not only the traditions of a culture; but they are important for research, according to Hegel, include public perception and "habits", and "convenience of life", and much more, i.e. a mentality.

German philosophers and theorists of culture A. Schopenhauer, F. Nietzsche, O. Spengler explained the existence of a self through a state of mind: intuition, human instincts, joy, fear, will, admiration, love, etc., at present the culture of the urban environment is being formed and does not account for essentially the informative presentation of human existence [18]. Culture of creating a sustainable urban environment is considered in dialectical unity of order and chaos: the gradual change of order and chaos.

The purpose and meaning of landscape design and of creating a sustainable urban environment is to connect the usual comforts of life and create a comfortable situation in the world corresponding to the spirit and intentions.

The attitude to the place of residence formed the basis of quality, satisfaction of higher (socio-cultural) and primary (basic) human needs and assess the degree of favorability (increasingly unfavourable) environment.

Based on the methodological principles of historicism and anthropology, urban environment should be as a continuum of coexistence, communication, interactions, relationships and needs of different nature and level, as a socio-cultural space of human life.

Life comfort, self-actualization, success or missuses, satisfaction or dissatisfaction with life depend on the environment the person creates by the deeds, actions, emotions and culture of those who organize the territory and lives in the area. The city is the way of the development and maintenance of sociality, reproduction and conservation values, the creation and distribution of intellectual and spiritual atmosphere, culture, attitudes, behavior. Residents coming in contact with the urban environment, give to it their own emotions, soul, consciousness, attitude, extracting from it what is interesting to them and valuable [12]. This environment, marked and transformed by the presence of a person is called the human environment, in relation to the city - urban environment.

Jean Baudrillard emphasized the interaction and mutual influence of a man and the surrounding space: "the Space given to him (man) as a distribution structure, and through control over the space he holds in his hands all options for the relationship..." [4, p. 31]. 
Philosopher A. Camus views the contact of man with nature, the surrounding world. He believes that man is helpless in connection with the nature, existing for millions of years ("I smell the grass and see the stars, but there is no knowledge on Earth which can give me the assurance that this is my world") [11, p. 160]. According to Camus, the meaning of life is deep in existence of man, and not in his external world (relationships, failures, successes). Therefore, the person is responsible for the preservation of natural landscapes and components of nature in the formation of the urban environment.

Philosophical search in the field of cultural theory, aesthetics of nature, landscape led to the formation of the subject-object system models in the understanding of beauty. Its origins are viewed in materialistic (Socrates, Aristotle, Diderot), and idealistic (Plato, Kant, Hegel, Soloviev) philosophical thought. The essence of this model is the recognition of objective foundations in aesthetic harmony of the surrounding world.

Tyumen philosopher L. N. Shabatura believes that in any activity, including project, it is necessary to preserve the "genetic code" that supports the traditions of the society. Saving the tradition of ancestors, we can pass to the next generation the nature of the cultural core of society [20]. True culture should be clear, accessible, rooted in the tradition.

Extending knowledge of the cultural values of the past contributes to the development of ecological, aesthetic, moral, historical and cultural education of future generations. From the standpoint of the structural-functional approach the urban environment can be seen as an open system (Park, square, street, promenade, Boulevard, yard, quarter, pedestrian street) and closed spaces (interiors of various functional areas). Differently organized human environment inevitably affects the behavior, psycho - emotional state of a person, his perception and understanding of space. The cultural heritage of society fits in the space of an artificial environment, created by a man.

Contemporary urban environment of the post-modernist period is not a harmonious space for better organization of work and rest of the population. The transformation of the urban environment in general is connected not only with economic aspects of production, and increasingly affects affects the ideological sphere, as it bringing up a new man, bringing certain aesthetic tastes, nature, beauty, harmonization to the surrounding space. Huge humanistic, socio-cultural potential of design was identified by prominent architects and designers in America and Europe. They are Alvar Aalto, Antoni Gaudi, Henry van de Velde, Walter Gropius, gio Ponti, George Nelson, Henry Dreyfuss, Charles Le Corbusier, Thomas Maldonado, Raymond Lowe [15]. But in the formation of the modern environment of Russian cities, this potential, in the majority, not used as one of the main factors of the culture of the urban environment.

Culture of creating a sustainable urban environment is a socio-cultural phenomenon that is formed and developed in the context of a specific social space, historical time. In the modern Russian society there are changes that we see as anti-cultural transformation. Such transformations destroy the historically established spiritual and moral foundations of society. The higher principles of the human being - kindness, justice, mercy, compassion, love of neighbour, have been replaced by the priority of the functional principles (efficiency, rationality, pragmatism).

\section{The problems of the forming of the urban environment}

As a result of anthropogenic loads a lot of valuable landscapes and suburbs were lost: deteriorating of water, air, chemical and mechanical composition of the soil. Highly urbanized environment affects health of people, causing physical, mental fatigue and, as a consequence, a disorder of the nervous system which cannot cope without medical intervention[13].

Contemporary urban environment contains a lot of unresolved social and cultural problems: the lack of General principles and laws governing the formation of the urban 
environment; growing environmental pollution; and ill-defined aesthetic; functional disorder; violation of architectural harmony with the needs of the patient; elimination of functional courtyard spaces; the destruction of the historic environment in the peripheral areas of the city; the erosion and disappearance of the spiritual filling of the urban space; the substitution of natural elements of the environment on artificially created; the impersonality of open spaces; the prevalence of utilitarianism and asceticism in shaping of the urban environment; irreversible changes in the chemical and mechanical composition of soils; replacement of courtyard spaces not authorized by the parking areas, etc.

Appeal to the problems of the urban environment allows one to realize the potential of landscape design to achieve a harmonious relationship of natural and artificial landscape components of the urban environment. The vector of design development should be focused on the transformation of the human environment, ensure compliance with the urban environment of new social relations. Considering design as a philosophical trend, one can conclude that the leading direction of a landscape designer is to create a sustainable urban environment should be the development of natural-environmental relations, the formation and maintenance of the environmental conditions, holistic systems, harmonizing the object - spatial environment and contributing to the preservation and development of culture.

The aim of landscape design consists of creating a sustainable urban environment as an organic fusion of architecture with natural components. The best works of architects (K. Tanghe, A. Aalto and F. Wright) based on the principle of holistic solutions for the building and its environment with a detailed design study of the elements of microlandscape. The landscape design provides the connection and organization of human environment, contributes to the synthesis of artificial and natural components of the environment. The necessary transition to the formation of the urban environment as a holistic space with a reassessment of its effects on the residents with the needs of the citizens in the required level of comfort and maximum preservation of natural components.

a)


Fig. 1. Tyumen, Respubliki Street. a) 1960; b) 2016

For human life is necessary not just a preserved nature in the urban environment but the landscape, aesthetically and structurally appropriate to the contemporary needs of society [13]. Thus, landscape design makes it possible to achieve functional order of urban spaces which is the most important quality of the environment associated with its sustainability.

To solve emerging problems and predict and prevent their rising should be taken implemented modern trends of landscape design in creating a sustainable urban environment: the transition to a holistic interpretation of urban space; efficient use of the landscape components of urban open spaces; consideration of human needs to ensure the necessary level of comfort; the achievement of functional orderliness, visual expression of 
landscape objects urban environment; improvement of the environment of urban spaces; creative transformation of nature; the formation of the awareness of urban space; the improvement of personal culture, the formation of a new worldview, a new co evolutionary interactions with the environment.

Landscape design projects a surrounding space as a full-fledged object of intellectual attention, the object with content and meaning. The appearance of the urban environment formed by the methods of landscape design is becoming more sensitive to the man, his relations with the outside world.

Operating with the space, its shape, color, light, bulges, depressions, rhythm, meter, contrast, nuance, landscape design affects a person, that is deeper than any word and meanings, what determines the sense of words and meanings, affects the core of being.

Landscape design, developing and enriching its own methodology, becomes the art of self-development. The task of landscape design is the individualization of the project results, the implementation in practice of modern design trends, methods of creating a sustainable urban environment.

The main task of design is not "beauty". It is an instrument, a consequence of deeper processes. The keyword for design is project. Landscape Design is not just about creating habitat. It is the construction of such a creation in principle, the making of a conscious, systematic, "deliberate", based on the rules, techniques, methods, which are realized by the Creator (designer). Landscape design - professional designing of a harmonious urban environment of self-worth in this activity. Methods of landscape design [19] is the theory in action. The main function of the methods of landscape design is the organization and management of practical transformation of the landscape object in a harmonious, aesthetically pleasing environment.

Implementing the features of the landscape design for the humanization of the environment, gives a person the chance to live, in the urban space with environmental sustainability, which implies the ability of nature to heal itself.

\section{Ways and means of solving the problems of the urban environment}

To solve the problems of creating a sustainable urban environment, it is necessary to apply a set of interrelated technical, social, environmental, ethical, aesthetic and other measures. At this point of view, we can use landscape design as a set of methods to create a sustainable urban environment for harmonious human life. Philosophical sense of the culture of creating a sustainable urban environment is to develop methods and principles that are commensurate with the severity of the real problems of society [3]:

The principle of environmental sustainability - the ability of nature to self-regulation through the use of "living" building materials, ensuring the conservation of nature, subject to the conditions of plant growth, the level of pollution of water, air, soil. The principle does not develop chaotic influence of the city on its natural environment.

The principle of aesthetic perfection - the light of artistic, architectural, compositional regularities of formation; organization of space with regard to their diversity, expressiveness, colors that creates visual comfort, eliminating uncomfortable faceless space through the rational use of natural ingredients.

The principle of universality is a fundamental principle of a sustainable urban environment. Creating an accessible environment for all categories of the population, taking into account the interests of all age groups of healthy people and the requirements of all categories of people with limited mobility.

The principle of economic efficiency implies an efficient use of labor and resources required to achieve a useful result. 
The principle of humanization counts the needs of different socio-demographic groups of the population: it is necessary to include anthropometric requirements (height of steps and handrails of stairs, height and dimensions of tables and benches, tilting seat backs, dimensions of baby equipment); sanitary-hygienic requirements (regulate such parameters of the environment like temperature, light, noise, physical and chemical composition of the air); the emotional and psychological demands associated with the peculiarities of human perception of information (color, graphics).

The principle of continuity - provides the cultural sensitivity in the design of landscape objects in the urban environment.

The principle of multilevel vertical structure - provides multi-level landscaping with the traditional placement of green spaces in the ground level - vertical greening of roofs, terraces. To improve green planting in public spaces it is necessary to use all available plots: slopes, ramps, walls, engineering structures, terraces, etc.

The principle of diversity - takes into account the design of the sequence of exchangeable visual plans in the formation of green spaces in the city.

The principle of space integration, creating a single environment for living and recreation: the formation of private spaces (through the organization of apartment green areas - gardens); neighborhood spaces are created for residents of one yard; public spaces are formed for relaxation and communication between people regardless of place of residence.

The principle of the "flowing" interior and open space can be done using two approaches: use in interior environments of landscape inclusions (microlandscapes) becomes the condition of its high quality; design of stylobates (interpretation of the earth's surface surrounded by buildings).

The bionic principles (imitation of natural forms) - the principle of structural-functional analogies of nature and of a design object. The facilitator of the visual expression of design ideas are the objects of nature. Bionic principle in design is based on establishing the structural and functional unity of the formation process of artificial and natural systems, resulting in possible ergonomic and visual harmonization of objects and subjects of the universe.

The variety of the used principles allows to expand organizational opportunities of formation of a sustainable urban environment. Landscaping, being philosophically significant action, promotes design of an urban environment as the system, sociocultural, dynamically developing object of intellectual attention. Landscaping projects surrounding space as full-fledged object of intellectual attention, object with contents and sense [14]. The shape of an urban environment created by methods of landscaping becomes more sensitive to the person, his relations with world around. Operating with space, his form, color, light, cambers, hollows, a rhythm, meter, contrast, nuance, landscaping affects in the person that is deeper than any words and meanings, what defines with what there will be these words and meanings. Touches feeling of life. Landscaping, developing and enriching own methodology, becomes self-development art. A problem of landscaping is individualization of results of the project, introduction in practice of design of current trends, methods of formation of a steady urban environment.

\section{Conclusion}

The main task of design is not "beauty". It is an instrument, a consequence of deeper processes. The keyword for design - design. Landscape design is not just about creating habitat. It is the construction of such a creation in principle, the making of a conscious, systematic, "deliberate", based on the rules, techniques, methods, which are realized by the Creator (designer). Landscape design - professional designing of a harmonious urban environment of self-worth in this activity. Methods of landscape design is the theory in 
action. The main function of the methods of landscape design is the organization and management of practical transformation of the landscape object in a harmonious, aesthetically pleasing environment.

Implementing the features of the landscape design for the humanization of the environment, gives a person the chance to live in the urban space with environmental sustainability, which implies the ability of nature to heal itself

Spiritually rich, culturally shaped the urban environment has artistic taste, shapes the thinking, behavior, attitude, outlook and the whole culture of modern citizens. The preservation and development of culture prevents the extremity of civilization, to which both tends the world.

\section{References}

1. A.S. Akhiezer, L.B. Kogan, O.N.Yanitsky, Urbanizaciya, obshchestvo i nauchnotekhnicheskaya revolyuciya, 2, 44-52 (1969)

2. N.V. Bauer, L.N. Shabatura, Vestnik Ishimskogo GPI im.Ershova, 3, 4-9 (2013)

3. N. V. Bauer, Kul'tura formirovaniya ustojchivoj gorodskoj sredy metodami landshaftnogo dizajna: dis (2015)

4. Z. H. Bodrijyar, Sistema veshchej (Rudomino, Moscow, 1999)

5. M. Veber, Izbrannye proizvedeniya (Progress, Moscow, 2012)

6. G.V.F. Gegel', Lekcii po ehstetike (Nauka, Sankt Peterburg, 1999)

7. G.V.F. Gegel', Lekcii po istorii filosofii (Nauka, Sankt Peterburg, 1993)

8. O.I. Genisaretskij, E.M. Bizunova, Teoriya dizajna. Teoreticheskie i metodologicheskie issledovaniya $v$ dizajne (SHkoly Kul'turnyj Politiki, Moscow, 2004)

9. G. Zimmel', Ponyatie i tragediya kul'tury, Izbrannoe (Filosofiya kul'tury, Moscow, 1996)

10. I. Kant, Kritika chistogo razuma (Ehksmo, Moscow, 2007)

11. A. Kamyu, Buntuyushchij chelovek (Politizdat, Moscow, 1990)

12. V.A. Nefedov, Gorodskoj landshaftnyj dizajn (Lyubavich, Sankt Peterburg, 2012)

13. V.A. Nikolaev, Landshaftovedenie: ehstetika $i$ dizajn landshafta (Aspekt Press, Moskva, 2003)

14. E. A. Orlova, Problemno orientirovannoe sociokul'turnoe proektirovanie. Teoriya $i$ metodologiya. Teoreticheskie osnovaniya kul'turnoj politiki (RIK, Moscow, 1993)

15. D.O. Sajmonds, Landshaftnaya arhitektura (Strojizdat, Moskva, 1965)

16. L.G. Skul'movskaya, Gorodskaya sreda kak substrat kul'tury goroda (INFO-DA, Sankt Peterburg, 2004)

17. O.S. Hpengler, Zakat Evropy (Mysl', Moskva, 1998)

18. A. Schopenhauer, Sobranie sochinenij: v 6 t. (TERRA - Knizhnyj klub, Moscow, 2001)

19. N.-S. C. Genius Loci, Paesaggio, Ambiente. Architettura. (Electa, Milano, 1979)

20. L.N. Shabatura L.N., O.E. Yatsevich, Gumanitarnye i social'nye nauki, 2, 156-162 (2014) 